\title{
The Uses of Use
}

\author{
Sara Ahmed:
}

What's the use. On the uses of use

Duke University Press, 2019, pages 296. Price 26,95 \$

\author{
By Camilla Sabroe Jydebjerg \\ Lecturer, University College Absalon University
}

What's the use from 2019 is the completion of a trilogy in which Sara Ahmed "follows words around, in and out of their intellectual histories." To Ahmed, "Thinking about the use of words is to ask about where they go, how they acquire associations, and in what and whom they are found" (p. 3). The trilogy starts with 'the promise of happiness' from 2010 and is followed by 'Willful subjects' from 2014. In a sense this third book about use is a meta-book as use has been an underlying concept of all three books. In the first book it was the uses of happiness at play. In the second, the uses of will, and finally in this third installment it is the uses of use that is being investigated. In all three books Ahmed shows how words are performative in the sense that they make us orient ourselves toward the emotions that they entail. Being happy. Being willful. Being useful.

The book also writes itself into Ahmed's larger work and grapples with many of this works reoccurring themes such as embodiment, orientations, diversity-work, complaints, fitting and misfitting, etc. In her work Ahmed shows us how "phenomenology helps us explore how the familiar is that which is not revealed. A queer phenomenology shows how the familiar is not revealed to those who can inhabit it" (Ahmed 2010b, p. 3). Instead it is up to the estranged, the strays, the misfits, the wretched, the queers "and other others" to be killjoys and reveal the familiar. "This is why being a killjoy can be a knowledge project, a world-making project" (Ahmed 2010b, p. 3). Together the trilogy is a beautiful killjoy project making it possible for us to reflect on our affective attachments to happiness, willfulness and usefulness accentuating how emotions are never just a private matter "but that they create the very effect of the surfaces or boundaries of bodies and worlds" (Ahmed 2004a, p. 117).

Where the earlier books focus on words that "seem to reference a subject", an important point of this book is how use and usefulness are intimately connected to things (p. 5). Ahmed shows how use is "a contact zone". A matter of how we come "into contact with things" (p. 40). In an impressive tour de force of things, through the book we become 
acquainted with a postbox now functioning as a bird's nest, a worn out back-pack, letters, used books, an empty tube of toothpaste, pathways and doorways, a puddle, multiple signs, a broken cup, and a pot figuring in Silas Marner by George Eliot. Through these encounters Ahmed shows how our relationship to things leave an impression that is as intimate as it is social. Things can make life easier for some and harder for others. On her blog Ahmed explains that scholarship in disability studies was a primary source of inspiration in writing the book "since reflecting on usability is to reflect on who a world is built for" (Ahmed 2019, para. 2). Through the encounters with things Ahmed shows how "worlds are built to enable some to fit, and not others" (p. 224). Ahmed further demonstrates how the use of things can form a normalizing path. A way for us to orient ourselves towards particular uses and less so against others. Using something a specific way makes other uses of the same kind easier. "The more a path is traveled upon the clearer it becomes" (p. 120).

Ahmed ties use and the uses of use to utilitarianism and its history and shows how the inheritance of utilitarianism has left us with a notion of disuse as a form a degeneracy. If an arm is not lifting it becomes a degenerate arm. It becomes useless. Ahmed also shows how the imperative to be useful befalls some bodies more than other bodies and how this is connected to both class and colonialism. Utilitarian thinkers were involved in educational projects e.g. the creation of monitorial schools for children of the working classes as well as children in the British colonies. Use thus became an educational technique directing children towards useful ends and "justifying colonialism as increasing happiness" (p. 10). Occupation of lands and bodies "can be narrated as taking care of things" (47). "Sympathy itself can be repurposed as tool" (p. 106). This also applies to adults who must also be steered away from vacancy, idleness, and unemployment.

This part of the book had a special resonance for me as I am currently doing research concerning Danish unemployment legislation. A utilitarianist mindset is not hard to spot here. The law contains an activation measure called utility jobs. These are jobs that are explicitly deemed useful for society. Unemployed people must commit to these jobs as a condition for receiving their benefits. It is further a requirement that you take on precarious temporary work. If you work less than 225 hours a year your benefits will be deducted. The rules treat people receiving benefits "as the limbs of a social body, as being for others to use" (p. 11).

Ahmed further demonstrates how utilitarian thought was deeply involved in shaping the modern university showing how neo-liberal thought is tied to a longer history of utilitarianism. Being a university worker involved in education I find Ahmed's analysis very compelling as she beautifully shows how uses shapes both thoughts and doings. "Institutions are built from small acts of use from uses of use, from how building blocks put together, over time, become walls, walls that enable some bodies to enter, stay put, progress, others not", as Ahmed explains (p. 191). This may also leave a potential for putting the blocks together differently. This is what Ahmed's phenomenological analysis opens up for. The possibility of putting the blocks together differently by becoming aware of and questioning our own familiar grounds.

In the book's hopeful conclusion, Ahmed calls for thinking about use in other ways. For a queering of use. "Queer use might refer to how things can be used in ways other than how they were intended to be used or by those other than for whom they were intended" (p. 44). I recommend that everyone reads this book (as well as Ahmed's other books) as a call for a solidary querying and queering of use. "Solidarity involves commitment, and work, as well as the recognition that even if we do not have the same feelings, or the same lives, or the same bodies, we do live on common ground" (Ahmed 2004b, p. 189). Let us all become killjoys together! Being a killjoy is a responsibility that should not only be shouldered by some. It should be carried by everyone - all of us - living on common ground whether this ground feels familiar or less familiar underneath our feet. 


\section{References}

Ahmed, S. (2004a). Affective Economies. Social Text 22(2), 117-139.

Ahmed, S. (2004b). The Cultural Politics of Emotion. Edinburgh: Edinburgh University Press.

Ahmed, S. (2010a). The Promise of Happiness. Durham: Duke University Press.

Ahmed, S. (2010b). Feminist Killjoys (And Other Willful Subjects). The Scholar and Feminist Online. 8 (3).

Retrieved from http://sfonline.barnard.edu/polyphonic/index.htm

Ahmed, S. (2014). Willful Subjects. Durham: Duke University Press.

Ahmed, Sara (2019, October 31.). The Same Door (blog post). Retrieved from https://feministkilljoys. com/2019/10/31/the-same-door/ 